\title{
Paddy Farmers' Adaptation Practices to Climatic Vulnerabilities in Malaysia
}

\author{
Md. Mahmudul Alam* \\ Postgraduate Student \\ Institute for Environment and Development (LESTARI) \\ National University of Malaysia (UKM), Malaysia; \\ Email: rony000@gmail.com \\ Chamhuri Siwar \\ Emeritus Professor \\ Institute for Environment and Development (LESTARI) \\ National University of Malaysia (UKM), Malaysia \\ Email: csiwar@ukm.my \\ Rafiqul Islam Molla \\ Professor and Specialist in Economics \\ Faculty of Business and Law \\ Multimedia University, Malaysia \\ Email: rimolla@gmail.com \\ Basri Talib \\ Associate Professor \\ Faculty of Economics and Business \\ National University of Malaysia (UKM), Malaysia \\ Email: basri@ukm.my \\ Mohd Ekhwan bin Toriman \\ Associate Professor \\ School of Social, Development \& Environmental Studies (FSSK) \\ National University of Malaysia (UKM), Malaysia \\ Email: ikhwan@ukm.my
}

\section{Citation Reference:}

Alam, M.M., Siwar, C., Molla, R.I., Talib, B., and Mohd Ekhwan, T. 2012. Paddy Farmers' Adaptation Practices to Climatic Vulnerabilities in Malaysia, Mitigation and Adaptation Strategies for Global Change, 17(4), 415-423. (Online) http://dx.doi.org/10.1007/s11027-011-9333-7

This is a pre-publication copy.

The published article is copyrighted by the publisher of the journal.

\footnotetext{
* Corresponding Author
} 


\title{
Paddy Farmers' Adaptation Practices to Climatic Vulnerabilities in Malaysia
}

\begin{abstract}
The climatic factors in Malaysia have been changing very rapidly affecting agricultural productivity and farmers' sustainable livelihood. Agriculture which depends heavily on climate is becoming increasingly vulnerable to risk and uncertainty. In order to face and manage the situation farmers are trying in various ways to adapt to these climatic vulnerabilities. This study analyses paddy farmers' perception of climatic variations and vulnerabilities and focuses on the techniques they use to adapt to the situation. It uses primary data collected through a questionnaire survey on the paddy farmers in the Integrated Agricultural Development Area (IADA), North-West Selangor in Malaysia. Through a descriptive analysis of the data, the study finds that most farmers do not have a clear perception of the climatic changes and vulnerabilities. Farmers' adaptation practices to the climatic vulnerability are mostly based on their common sense responses. It suggests that farmers need necessary training and support from the government and international agencies to make them able to effectively adapt to the climatic vulnerability and avert any adverse effect on their socioeconomic sustainability and national food security.
\end{abstract}

Key words: Agricultural Sustainability; Climate Change; Climatic Vulnerability; Adaptation Technique; Farmer; Paddy; Malaysia

\section{Introduction}

Malaysia, with a population of about 27 million, is currently the 26th largest greenhouse gas emitter in the world. It may quickly move up on the list due to high growth rate of emissions as a result of agricultural and industrial expansion in the country. Due to high greenhouse gas emissions the temperature is projected to rise by $0.3-4.5^{\circ} \mathrm{C}$. Warmer temperature will cause sea level to rise by about $95 \mathrm{~cm}$ over a hundred-year period. The changes in rainfall may fluctuate from about -30 to $+30 \%$. This change will reduce crop yield. It may cause drought in many areas so that cultivation of some crops such as rubber, oil palm, and cocoa will not be possible (NRS 2001). The projection shows maximum monthly precipitation will increase up to $51 \%$ in Pahang, Kelantan and Terengganu, and the minimum precipitation will decrease by $32-61 \%$ for the entire Peninsular Malaysia. Consequently, annual rainfall will increase by $10 \%$ in Kelantan, Terengganu, Pahang and North-West Coast and decrease by 5\% in Selangor and Johor (NAHRIM 2006). This variation in climatic factors will cause the agricultural system to become vulnerable to risk and uncertainty.

The average temperature in the rice growing areas in Malaysia is about $26^{\circ} \mathrm{C}$. Under current climatic change scenario, temperature above $25^{\circ} \mathrm{C}$ may cause decline in grain mass by $4.4 \%$ per $1{ }^{\circ} \mathrm{C}$ rise in temperature (Tashiro and Wardlaw 1989) and grain yield may decline as much as $9.6-10.0 \%$ per $1{ }^{\circ} \mathrm{C}$ rise (Baker and Allen 1993). Singh et al. (1996) shows that in Malaysia the actual yield of paddy rice per hectare vary from 3-5 tons, when the potential yield is 7.2 tons. There is a decline of paddy rice yield between $4.6-6.1 \%$ per $1{ }^{\circ} \mathrm{C}$ temperature increase under the present $\mathrm{CO}_{2}$ level. But a doubling of $\mathrm{CO}_{2}$ concentration (from present level of 340-680ppm) may offset the detrimental effect up to $4^{\circ} \mathrm{C}$ temperature increase. In a recent study it is found that a $1 \%$ increase in temperature leads to a $3.44 \%$ decrease in current paddy yield and $0.03 \%$ decrease in paddy yield in next season; and a $1 \%$ 
increase in rainfall leads to $0.12 \%$ decrease in current paddy yield and $0.21 \%$ decrease of paddy yield in next season (Alam et al. 2010c).

Tisdell (1996) finds that rainfall variability increases the level of environmental stress which adversely affects the ability of the system to maintain productivity. It is projected that in Malaysia any change in rainfall, both positive and negative, by more than only $0.4 \%$ by 2020 will cause decline in paddy yield (NRS 2001). Alam et al. (2011a) indicate that the yearly total rainfall is increasing and its monthly variation is too high. The adverse effects of lower rainfall can be reduced or averted by introducing proper irrigation system. But the effect of the opposite phenomenon of over rainfall especially at the end of the crop cycle or at the maturity period is absolutely uncontrollable.

As climatic change is a continuous process, its effects and solutions are also similarly time and efforts consuming processes. Most of the global warming during the next 30 years will be due to emissions that have already occurred. Over the longer term, the degree and pace of warming mainly depend on current and near future emissions (Stern 2007). In recent years, adaptation has gained prominence as an important response measure especially in vulnerable countries. Even though it has become clear that some impacts are now unavoidable in the short to medium term.

According to IPCC (2001), adaptation refers to adjustments in ecological, social or economic systems in response to actual or expected stimuli. This term refers to changes in processes, practices, and structures to moderate potential damages or to benefit from opportunities associated with climatic change. It outlines few basic principles like a) adaptation to short-term climatic variability and extreme events for reducing vulnerability to long-term climate change; b) adaptation policy and measures in a developmental context; c) adaptation at different levels in society; d) and the adaptation strategy and the process. According to UNDP (2005), a climate change adaptation strategy for a country refers to a general plan of action for addressing the impacts of climate change. It may include a mix of policies and measures, selected to meet the overarching objective of reducing the country's vulnerability. Under current climatic change scenario, adaptation strategies are crucial for vulnerable groups because failure to adapt could lead to deprivation, social disruption and population displacement, and even morbidity and mortality (Downing et al. 1997). As a result, different countries have applied different approaches and techniques to adapt with climatic vulnerabilities. Malaysia is in the process of developing its adaptation policy for averting the adverse climatic impacts.

\section{Data and Methodology}

To determine the nature and extent of farmers' adaptation to climatic vulnerability in Malaysia, this study relies on the primary data collected under a research project on economics of climatic change at the Institute for Environment and Development (LESTEARI), National University of Malaysia (UKM). It was funded by the Ministry of Science, Technology and Environment, Government of Malaysia (Alam et al. 2010a). It is a case study of Malaysia's paddy sector. Data were collected through a random sample survey of paddy producing farmers in the eight sections of the Integrated Agricultural Development Area (IADA) of North-West Selangor, Malaysia during 2009-2010 (Fig 1). The IADA covers an area of 100,000 hectare (ha). 55,000 ha are marked for cultivation of palm oil, 20,000 ha for coconut, 5,000 ha for fruits and vegetables, and 20,000 ha for paddy. This 20,000 ha for paddy cultivation include major rivers, (i.e Sungai Sireh and Sungai Karang), a 75 km 
irrigation system, and other infrastructures. Currently paddy is cultivated on 18,355 ha leaving 625 ha for drainage. There are a total of 10,300 paddy farmers and 30,000 other crops producers in the IADA. A population of about 50,000 forms the total size of the agricultural community in the area.

\section{$<$ Figure 1>}

The survey was conducted by regular enumerators of the IADA authority using a structured questionnaire under the direct supervision of IADA officials. Data were collected from a sample of 198 paddy farmers proportionately distributed among the eight areas. Details of socioeconomic profiles of the respondents are available at Alam and others $(2010 \mathrm{~b}$, 2010d, 2011c). This study uses a 5-point scale with 1 as very low and 5 as very high for measuring farmers' perceptions of change in climatic factors and the extent of their adaptations. The data have been analysed under a descriptive framework using descriptive statistics, percentile and ordinal scale.

\section{Farmers' Perception of Climatic Vulnerability}

Farmers are the directly affected group and close observers of climatic change and vulnerability (Siwar et al. 2009, Alam et al. 2011b). Their understanding about climatic vulnerability differs largely. Overall, $40.9 \%$ of farmers have no idea about climatic change and vulnerability.

\section{<table 1>}

$53.3 \%$ farmers understand climatic vulnerability as increase in temperature or change in temperature and for $55.6 \%$ farmers climatic vulnerability is unpredictable rainfall or changes in rainfall. For $43.2 \%$ farmers it means drought; for $46.5 \%$ farmers it is increase in flood. To $53.3 \%$ farmers, rise in sea level is an indicator of climatic vulnerability.

<table 2>

\section{Farmers' Approaches towards Adaptation}

Various farmers take various types of measures to adapt with the climatic vulnerability. Their approaches vary based on their perceptions, knowledge, locations, availability of resources, cropping patterns, nature and degree of vulnerability, etc.

83.8\% farmers mostly rely on using chemical fungicide and pesticide to cope with the insect and paste attacks. Some try to seek solution to the problem through natural process such as by changing the crop planning schedules. They try to produce chemical free crops, especially vegetables. In Malaysia, chemical free crops (or organic crops) have good market and their prices very high. For example, the prices of organic vegetables could be more than three times the prices of non-organic vegetables.

\section{$<$ table 3>}

IADA provides the irrigation facilities. Farmers are fully dependent on it for irrigation. When there is shortage of water supply for irrigation, farmers try to collect water from the drains and drainage area with the help of small water pumps. 
In case of low rainfall, farmers do not have proper idea how to cope with the situation. They rely on IADA for the solution.

$<$ table 5>

In case of excessive rainfall, farmers pump out water from the paddy fields. Other than this, they have no idea about how to protect the crop from the adverse effects of heavy rainfall.

$<$ table 6>

Nearly $44 \%$ of farmers add more water in the field for maintaining required moisture level during the time of high temperature or sunshine.

<table 7>

$40.4 \%$ farmers use organic fertilizer, $24.7 \%$ use lime, and $15.2 \%$ use chemical fertilizer to cope with soil fertility losses.

$<$ table 8>

When weeds grow on the crop field, farmers cut the weeds or use weedicide.

<table 9>

Farmers' adaptation practices to cope with the agricultural vulnerability due to climatic change are not found adequate and satisfactory (Alam et al. 2011d, 2011e). Their adaptation methods are based only on their ideas or reactions. As a result, only $30.3 \%$ farmers believe that they have been able to properly cope with climatic vulnerabilities.

<table 10>

\section{Conclusion and Recommendations}

The study finds that most paddy farmers do not have clear perception of climatic change and vulnerability. Most farmers understand that increases in drought, flood, and sea level are the results of climatic changes. 53.3\% of farmers feel that the temperature, one most important climatic factor, is changing, and $55.6 \%$ believe that the rainfall, the other most important climatic factor, is changing. To cope with the situation and avert any adverse effect, farmers are trying various methods to adapt to the changes in various climatic factors. However these methods are not found so effective. As a result the agricultural sector of the country is becoming increasingly vulnerable threatening farmers' livelihood sustainability and national food security. Paddy farmers in the study area, therefore, need necessary training and support from the government and the international agencies for better adaptation to climatic vulnerabilities. It is essential for agricultural sustainability and human livelihood sustainability. The options for agricultural adaptation can be grouped as technological developments, government programs, farm production practices, and farm financial management (Smit and Skinner 2002, Alam et al. 2010e). Accordingly, all necessary training and support should be given to the farmers by the government and international agencies to make them able to effectively adapt to the climatic vulnerabilities to avert any adverse effect 
on their livelihood sustainability and national food security (Alam et al. 2011f). Crop insurance may be considered as a more effective adaptation instrument and a viable option in this respect.

\section{Acknowledgement}

We are thankful to Ministry of Science, Technology and Environment of the Government of Malaysia for generously funding the research, under the Research University Grant (UKMGUP-PI-08-34-081). We would also like to thank Dr. Md. Wahid Murad (University of Adelaide, Australia) for his advices and supports at various stages of the study.

\section{References}

Alam MM, Siwar C, and Toriman ME (2010a) Socioeconomic Study of Climate Change: An Assessment of Agriculture and Livelihood Sustainability on Paddy Farming in Malaysia. LAP Lambert Academic Publishing, Saarbrucken.

Alam MM, Siwar C, Murad MW, Molla RI, and Toriman ME (2010b) Socioeconomic Profile of Farmer in Malaysia: Study on Integrated Agricultural Development Area in NorthWest Selangor. Agricultural Economics and Rural Development 7(2):249-26. ftp://www.ipe.ro/RePEc/iag/iag_pdf/AERD1013_249-265.pdf. Cited 05 Aug 2011

Alam MM, Talib B, Siwar C, Toriman ME (2010c) The Impacts of Climate Change on Paddy Production in Malaysia: Case of Paddy Farming in North-West Selangor. Proceedings of the international conference of the 4th International Malaysia- Thailand Conference on South Asian Studies. National University of Malaysia, Malaysia, Mar 25-26

Alam MM, Siwar C, Molla RI, Toriman ME, and Talib B (2010d) Socioeconomic Impacts of Climatic Change on Paddy Cultivation: An Empirical Investigation in Malaysia. Journal of Knowledge Globalization 3(2):71-84. http://journals.sfu.ca/jkg/index.php/journal/article/view/57/44. Cited 05 Aug 2011

Alam MM, Siwar C, and Al-Amin AQ (2010e) Climate Change Adaptation Policy Guidelines for Agricultural Sector in Malaysia. Asian Journal of Environmental and Disaster Management 2(4):463- 469. DOI 10.3850/S1793924011000873.

Alam MM, Toriman ME, Siwar C, and Talib B (2011a) Rainfall variation and changing pattern of agricultural cycle. American Journal of Environmental Science 7:82-89. DOI 10.3844/ajessp.2011.82.89. Cited 05 Aug 2011

Alam MM, Siwar C, Molla RI, Toriman ME, and Talib B (2011b) Climate Change and Vulnerability of Paddy Cultivation in North-West Selangor, Malaysia: A Survey of Farmers' Assessment. Voice of Academia 6(1):45-56.

Alam MM, Siwar C, Talib B, and Toriman ME (2011c) An Empirical Study on the Relationships between the Socioeconomic Profile of Farmers and Paddy Productivity in North-West Selangor, Malaysia. Asia-Pacific Development Journal 18(1): 161-173. http://www.unescap.org/pdd/publications/index_apdj.asp. Cited 05 Aug 2011

Alam MM, Toriman ME, Siwar C, Molla RI, and Talib B (2011d) The Impacts of Agricultural Supports for Climate Change Adaptation: Farm Level Assessment Study on Paddy Farmers. American Journal of Environmental Sciences 7(2): 178-182. DOI 10.3844/ajessp.2011.82.89. Cited 05 Aug 2011

Alam, MM, Siwar C, Toriman ME, Molla RI, Talib B (2011e) Climate Change Induced Adaptation by Paddy Farmers in Malaysia. Mitigation and Adaptation for Global Change 16(7), DOI: 10.1007/s11027-011-9319-5.

Alam, MM, Siwar C, Murad MW, Toriman ME (2011f) Impacts of Climate Change on Agriculture and Food Security Issues in Malaysia: An Empirical Study on Farm Level 
Assessment. World Applied Sciences Journal 14(3): 431-442. http://idosi.org/wasj/wasj14(3)11/12.pdf . Cited 05 Oct 2011

Baker JT, Allen JrLH (1993) Contrasting crop species responses to $\mathrm{CO}_{2}$ and temperature: rice, soybean and citrus. Vegetatio 104/105: 239-260. http://www.jstor.org/pss/20029749. Cited 05 Aug 2011

Downing TE, Ringius L, Hulme M, and Waughray D (1997) Adapting to climate change in Africa. Mitigation and Adaptation Strategies for Global Change 2:19-44. DOI: 10.1023/B:MITI.0000004663.31074.64

IPCC (Intergovernmental Panel on Climate Change) (2001) Climate Change 2001: Impacts, Adaptation and Vulnerability. IPCC Third Assessment Report, Cambridge University Press: Cambridge, UK

NAHRIM (2006) Final Report: Study of the Impact of Climate Change on the hydrologic Regime and Water Resources of Peninsular Malaysia, National Hydraulic Research Institute of Malaysia (NAHRIM) and California Hydrologic Research Laboratory (CHRL), Malaysia. http://www.nahrim.gov.my/download/pksa/RegHCM_PM_Report_9_21_06_Ex\%20v 1.pdf. Cited 05 Aug 2011

NRS (2001) National Response Strategies to Climate Change. Ministry of Science, Technology and the Environment, Malaysia. http://gedung.nahrim.gov.my/wapi/mctweb.dll/getObject?MID=WATER\%20RESOU RCES\&Sn=2038. Cited 05 Aug 2011

Siwar C, Alam MM, Murad MW, and Al-amin AQ (2009) A review of the linkages between climate change, agricultural sustainability and poverty in Malaysia. International Review of Business Research Papers 5(6):309-321. http://www.bizresearchpapers.com/23.\%20Siwar.pdf. Cited 05 Aug 2011

Smit B, and Skinner MW (2002) Adaptation options in agriculture to climate change: a typology. Mitigation and Adaptation Strategies for Global Change 7: 85-114. DOI: 10.1023/A:1015862228270

Stern N (2007) The Economics of Climate Change: The Stern Review. Cambridge University Press, Cambridge

Tashiro T, and Wardlaw IF (1989) A comparison of the effect of high temperature on grain development in wheat and rice. Annals of Botany 64:59-65

Tisdell C (1996) Economic indicators to assess the sustainability of conservation farming projects: An evaluation. Agriculture, Ecosystems and Environment 57(2):117-131

UNDP (2005) Adaptation Policy Framework for Climate Change: Developing Policies Strategies and Measures. In: Lim B, and Spanger-Siegfred E (eds). Cambridge University Press, Cambridge, UK 
Table 1: Farmers' Understandings about Climate Change Vulnerability

\begin{tabular}{lcc}
\hline \multicolumn{1}{c}{ Respondent View about Climate Change } & No. of Respond & \% of Total \\
\hline \hline Hot Temperature & 74 & $37.40 \%$ \\
Unpredictable Rain & 30 & $15.20 \%$ \\
Interferes with Cultivation Time & 6 & $3.00 \%$ \\
Natural Disasters & 1 & $0.50 \%$ \\
Drought & 2 & $1.00 \%$ \\
Pest Attack & 4 & $2.00 \%$ \\
Don't Aware & 81 & $40.90 \%$ \\
\hline Total & 198 & $100 \%$ \\
\hline
\end{tabular}

Table 2: Farmers' Views about Vulnerability of Climate Relevant Factors

\begin{tabular}{|c|c|c|c|c|c|c|c|c|c|}
\hline \multirow{2}{*}{$\begin{array}{l}\text { Climate } \\
\text { Factors }\end{array}$} & \multicolumn{5}{|c|}{ Observation Scale* } & \multirow{2}{*}{$\begin{array}{c}\text { Average } \\
\text { Value of } \\
\text { Scale }\end{array}$} & \multirow{2}{*}{ S.D. } & \multirow{2}{*}{$\begin{array}{c}\text { Agreed } \\
(4 \& 5) \\
\text { Respondent }\end{array}$} & \multirow{2}{*}{$\begin{array}{l}\text { Disagreed } \\
\quad(1 \& 2) \\
\text { Respondent }\end{array}$} \\
\hline & $\mathbf{1}$ & 2 & 3 & 4 & 5 & & & & \\
\hline \multirow{2}{*}{ Temperature } & 9 & 10 & 73 & 50 & 56 & \multirow{2}{*}{3.68} & \multirow{2}{*}{1.08} & 106 & 19 \\
\hline & $4.5 \%$ & $5.1 \%$ & $36.9 \%$ & $25.3 \%$ & $28.3 \%$ & & & $53.5 \%$ & $9.6 \%$ \\
\hline \multirow[b]{2}{*}{ Rainfall } & 6 & 7 & 75 & 67 & 43 & \multirow[b]{2}{*}{3.68} & \multirow[b]{2}{*}{0.95} & 110 & 13 \\
\hline & $3.0 \%$ & $3.5 \%$ & $37.9 \%$ & $33.8 \%$ & $21.7 \%$ & & & $55.6 \%$ & $6.6 \%$ \\
\hline \multirow{2}{*}{$\begin{array}{l}\text { Sea Level } \\
\text { Increase }\end{array}$} & 14 & 15 & 63 & 66 & 40 & \multirow{2}{*}{3.52} & \multirow{2}{*}{1.11} & 106 & 29 \\
\hline & $7.1 \%$ & $7.6 \%$ & $31.8 \%$ & $33.3 \%$ & $20.2 \%$ & & & $53.5 \%$ & $14.6 \%$ \\
\hline \multirow{2}{*}{ Flood } & 13 & 11 & 82 & 61 & 31 & \multirow{2}{*}{3.43} & \multirow{2}{*}{1.03} & 92 & 24 \\
\hline & $6.6 \%$ & $5.6 \%$ & $41.4 \%$ & $30.8 \%$ & $15.7 \%$ & & & $46.5 \%$ & $12.1 \%$ \\
\hline \multirow{2}{*}{ Drought } & 12 & 11 & 91 & 48 & 36 & \multirow{2}{*}{3.43} & \multirow{2}{*}{1.04} & 84 & 23 \\
\hline & $6.1 \%$ & $5.6 \%$ & $46.0 \%$ & $24.2 \%$ & $18.2 \%$ & & & $42.4 \%$ & $11.6 \%$ \\
\hline
\end{tabular}

*Scale: 1 = Strongly Decreasing, 2 = Decreasing, 3 = Not sure, 4 = Increasing, 5 = Strongly Increasing

Table 3: Farmers' Adaptation Approaches for Injurious Insect

\begin{tabular}{lcc}
\hline \multicolumn{1}{c}{ Approaches } & No. of Respond & \% of Total \\
\hline \hline Biologically Control & 7 & $3.50 \%$ \\
Control at the beginning & 12 & $6.10 \%$ \\
Proper Scheduling of Cultivation & 7 & $3.50 \%$ \\
Spraying Fungicide and Pesticide & 166 & $83.80 \%$ \\
No Idea & 6 & $3.00 \%$ \\
\hline Total & 198 & $100 \%$ \\
\hline
\end{tabular}

Table 4: Farmers' Adaptation Approaches for Low Supply of Drainages Water

\begin{tabular}{lcc}
\hline \multicolumn{1}{c}{ Approaches } & No. of Respond & $\%$ of Total \\
\hline \hline Ensure Good Drainage & 18 & $9.10 \%$ \\
Inform the Authority & 2 & $1.00 \%$ \\
Pumps water from drainage & 160 & $80.80 \%$ \\
No Idea & 18 & $9.10 \%$ \\
\hline Total & 198 & $100.00 \%$ \\
\hline
\end{tabular}


Table 5: Farmers' Adaptation Approaches for Low Rainfall

\begin{tabular}{lcc}
\hline \multicolumn{1}{c}{ Approaches } & No. of Respond & \% of Total \\
\hline \hline Change the Timing of Cultivation & 3 & $1.50 \%$ \\
No Alternative Option & 20 & $10.10 \%$ \\
Pumps in Drainage & 114 & $57.60 \%$ \\
No Idea & 61 & $30.80 \%$ \\
\hline Total & 198 & $100.00 \%$ \\
\hline
\end{tabular}

Table 6: Farmers' Adaptation Approaches for Excessive Rainfall

\begin{tabular}{lcc}
\multicolumn{1}{c}{ Approaches } & No. of Respond & $\%$ of Total \\
\hline \hline Pumps water out of plot & 121 & $61.10 \%$ \\
No Idea & 77 & $38.90 \%$ \\
\hline Total & 198 & $100.00 \%$ \\
\hline
\end{tabular}

Table 7: Farmers' Adaptation Approacesh for High Temperature

\begin{tabular}{lcc}
\hline Approaches & No. of Respond & $\%$ of Total \\
\hline \hline Continuously Add Water & 7 & $3.50 \%$ \\
Maintain water at paddy plot level & 80 & $40.40 \%$ \\
No Alternative Option & 9 & $4.50 \%$ \\
Plant protective Big trees & 12 & $6.10 \%$ \\
No Idea & 90 & $45.50 \%$ \\
\hline Total & 198 & $100.00 \%$ \\
\hline
\end{tabular}

Table 8: Farmers' Adaptation Approaches for Soil Fertility Loss

\begin{tabular}{lcc}
\hline \multicolumn{1}{c}{ Approaches } & No. of Respond & \% of Total \\
\hline \hline Chemical Fertilizer Use & 30 & $15.20 \%$ \\
Limefication & 49 & $24.70 \%$ \\
Reduce chemical fertilizer usage & 3 & $1.50 \%$ \\
Use organic fertilizer & 80 & $40.40 \%$ \\
No Idea & 36 & $18.20 \%$ \\
\hline Total & 198 & $100.00 \%$ \\
\hline
\end{tabular}

Table 9: Farmers' Adaptation Approaches for Weeds

\begin{tabular}{lcc}
\hline Approaches & No. of Respond & \% of Total \\
\hline \hline Cutting grass & 19 & $9.60 \%$ \\
Weedicide & 161 & $81.30 \%$ \\
No Idea & 18 & $9.10 \%$ \\
\hline Total & 198 & $100.00 \%$ \\
\hline
\end{tabular}

Table 10: Farmers' Capabilities of Adaptation with Climatic Vulnerability 


\begin{tabular}{|c|c|c|c|c|c|c|c|c|c|}
\hline \multirow{2}{*}{$\begin{array}{l}\text { Types of } \\
\text { Supports }\end{array}$} & \multicolumn{5}{|c|}{ Observation Scale* } & \multirow{2}{*}{$\begin{array}{c}\text { Average } \\
\text { Value of } \\
\text { Scale }\end{array}$} & \multirow{2}{*}{ S.D } & \multirow{2}{*}{$\begin{array}{c}\text { Agreed } \\
(4 \text { \& 5) } \\
\text { Observation }\end{array}$} & \multirow{2}{*}{$\begin{array}{l}\text { Disagreed (1 } \\
\text { \& 2) } \\
\text { Observation }\end{array}$} \\
\hline & 1 & 2 & 3 & 4 & 5 & & & & \\
\hline $\begin{array}{l}\text { Able to Cope } \\
\text { Properly with } \\
\text { Climate Change }\end{array}$ & $\begin{array}{r}21 \\
10.6 \%\end{array}$ & $\begin{array}{r}38 \\
19.2 \%\end{array}$ & $\begin{array}{r}79 \\
39.9 \%\end{array}$ & $\begin{array}{r}36 \\
18.2 \%\end{array}$ & $\begin{array}{r}24 \\
12.1 \%\end{array}$ & 3.02 & 1.14 & $\begin{array}{r}60 \\
30.3 \%\end{array}$ & $\begin{array}{r}59 \\
29.8 \%\end{array}$ \\
\hline
\end{tabular}

*Scale: 1 = Strongly Disagree, 2 = Disagree, 3 = Not Sure, 4 = Agree, 5 = Strongly Agree

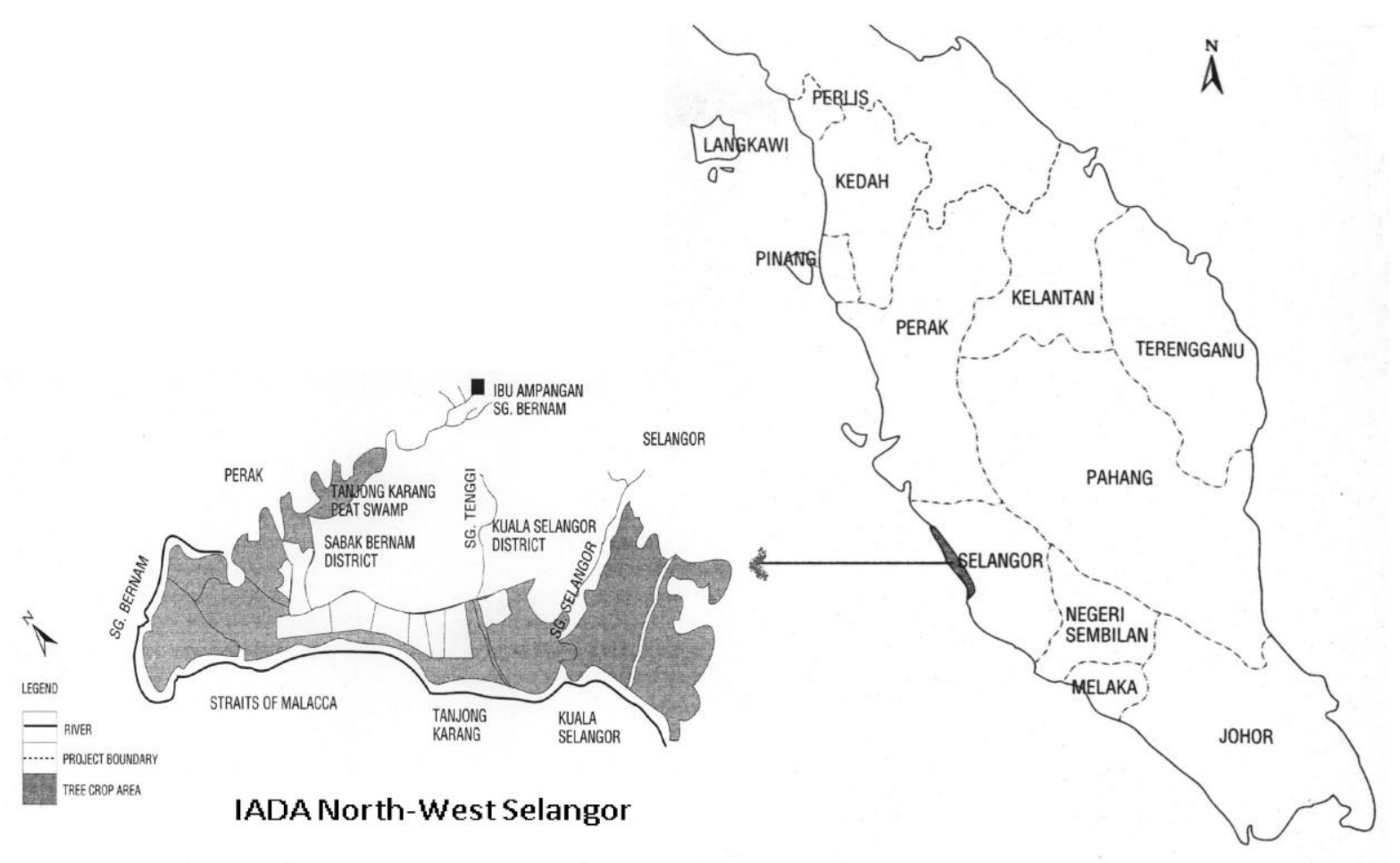

Figure 1: Location of study area, IADA in North-West Selangor, Malaysia 